\title{
Perencanaan Baja Ringan Sebagai Salah Satu Alternatif Pengganti Kayu Pada Struktur Rangka Atap Bangunan
}

\author{
M. Riza Primadani*, Suhendra, Eri Dahlan \\ Program Studi Teknik Sipil Universitas Batanghari Jambi \\ *Correspondence email: rizaprimadani@gmail.com
}

\begin{abstract}
Abstrak. Seiring perkembangan jaman, kebutuhan akan kayu sebagai bahan dasar rangka atap semakin meningkat, namun tidak diiringi dengan kualitas dan kuantitas kayu itu sendiri. Semakin langkanya pohon terutama pohon dengan kualitas kayu baik menyebabkan harga kayu menjadi relatif mahal. Hal ini menjadi dasar pemikiran produsen untuk menciptakan inovasi baru berupa baja ringan untuk membuat rangka atap. Baja ringan dipilih sebagai alternatif pengganti kayu sebagai rangka atap karena baja ringan memiliki faktor keawetan, tahan rayap dan tahan karat. Tujuan dari penelitian ini untuk menganalisis rangka kuda-kuda baja ringan dan kuda-kuda kayu, serta membandingkan besarnya biaya atap yang menggunakan konstruksi rangka baja ringan dan konstruksi rangka kayu. Material struktur kayu menggunakan material kayu kelas II dan material baja menggunakan Baja Ringan C75.75. Bangunan yang di jadikan objek adalah bangunan $72 \mathrm{~m}^{2}$ dengan luas area bangunan $8 \mathrm{~m}$ x $9 \mathrm{~m}$. Pada penelitian ini diperoleh Persentase harga pada kuda-kuda baja ringan 101,93\% kali harga pada kuda-kuda kayu. Dan persentase berat kuda-kuda baja ringan 11,25\% dari berat kuda-kuda kayu. Terdapat perbedaan biaya pada rangka atap yaitu pada pembangunan rangka atap baja ringan dengan luas $72 \mathrm{~m}^{2}$ didapatkan total biaya yang dikeluarkan sebesar Rp.63.278.178, Sedangkan menggunakan rangka atap kayu total biaya yang dikeluarkan sebesar Rp.62.082.444. Perbandingan biaya pada pembangunan rangka atap atap baja ringan dan rangka atap kayu adalah sebesar Rp.1.195.734. Jadi kesimpulan yang bisa diambil dari kedua perbandingan biaya tersebut adalah pembuatan rangka atap menggunakan rangka atap baja ringan lebih mahal dari pada biaya menggunakan rangka atap kayu.
\end{abstract}

Kata Kunci : Rangka Atap Kayu, Rangka Atap Baja Ringan, Material, Anggaran Biaya

\section{PENDAHULUAN}

Atap merupakan konstruksi bagian atas sebuah bangunan yang berfungsi sebagai penutup pada suatu ruang dari panas matahari, angin maupun hujan. Secara umum, masyarakat menggunakan material kayu sebagai kuda-kuda pada atap untuk rumah tinggal. Namun, material tersebut memiliki berbagai kendala terutama kurangnya ketahanan kayu terhadap rayap.

Peningkatan jumlah penduduk membuat permintaan akan hunian tempat tinggal dan tentunya permintaan rangka atap menjadi meningkat. Seiring perkembangan jaman, kebutuhan akan kayu sebagai bahan dasar rangka atap semakin meningkat, namun tidak diiringi dengan kualitas dan kuantitas kayu itu sendiri. Saat ini material kayu yang bagus kualitasnya semakin susah didapat dan harganya semakin mahal, sehingga pemakaian konstruksi kayu sebagai struktur rangka kuda-kuda dan rangka atap pada bangunan sudah mulai digantikan oleh konstruksi baja ringan. Baja ringan dipilih sebagai alternatif pengganti kayu sebagai rangka atap karena baja ringan memiliki faktor keawetan, tahan rayap dan tahan karat. (Devi, 2015)

Struktur baja ringan sudah lama di produksi di Indonesia, sejak 1973 oleh Perusahaan Australia (PT. BHP Steel Lysaght) dan sampai sekarang masih tetap eksis dan bahkan berkembang semakin maju. Seiring waktu, material baja ringan sudah sering digunakan pada konstruksi kuda-kuda sampai saat ini (Wiryanto 2018).

Pemakaian konstruksi baja ringan sebagai struktur rangka kuda-kuda dan rangka atap sudah semakin maju. Oleh karena itu, masih perlu pembahasan tentang analisa biaya konstruksi baja ringan. Berdasarkan hal tersebut di atas, maka rumusan masalah yang akan dibahas yaitu analisa biaya pada struktur rangka kudakuda baja ringan dan kuda-kuda kayu pada konstuksi bangunan.

\section{Landasan Teori}

Konstruksi Rangka Atap adalah suatu bentuk konstruksi yang berfungsi untuk menyangga konstruksi atap yang terletak di atas kuda-kuda.Fungsi rangka atap yang lebih spesifik adalah menerima beban oleh bobot sendiri, yaitu beban kuda-kuda dan bahan pelapis berarah vertikal kemudian meneruskannya pada kolom dan pondasi, serta dapat berfungsi sebagai penahan tekanan angin muatan yang berarah horizontal pada gevel. (Hesna dkk, 2009)

Konstruksi Rangka Atap Kayu 
Konstruksi Rangka Atap Kayu adalah suatu konstruksi yang berfungsi sebagai penahan beban penutup iatap, yang melindungi penghuni rumah dari panas matahari, angin dan air hujan, yang strukturnya terbuat dari rangka kayu.Konstruksi rangka atap dengan menggunakan bahan kayu untuk bentang $8 \mathrm{~m}$ menggunakan balok kayu mutu kelas II, dengan dimensi balok 8/10, dimensi gording 8/10 dengan jarak gording antara 1 m hingga $2 \mathrm{~m}$, dimensi kasau 5/7 dengan jarak kasau maksimal 0,5 m, dan dimensi reng 3/4 dengan jarak reng disesuai dengan jenis penutup atap, pada luas bangunan rumah tipe $8 \mathrm{~m}$ x $9 \mathrm{~m}$, menggunakan penutup atap genteng metal. Dengan jarak kuda-kuda 2,5 m.

Penggunaan kayu sebagai struktur rangka kuda-kuda membutuhkan waktu lama dibandingkan dengan fabrikasi kuda-kuda baja ringan. Hal ini disebabkan karena kayu adalah bahan yang berasal dari alam sehingga harus diolah terlebih dahulu sedemikian rupa sehingga dapat digunakan untuk membuat kudakuda.Karena melihat keberadaan kayu yang mulai tidak tentu, maka dianggap perlu untuk mencari material lain yang juga memadai.

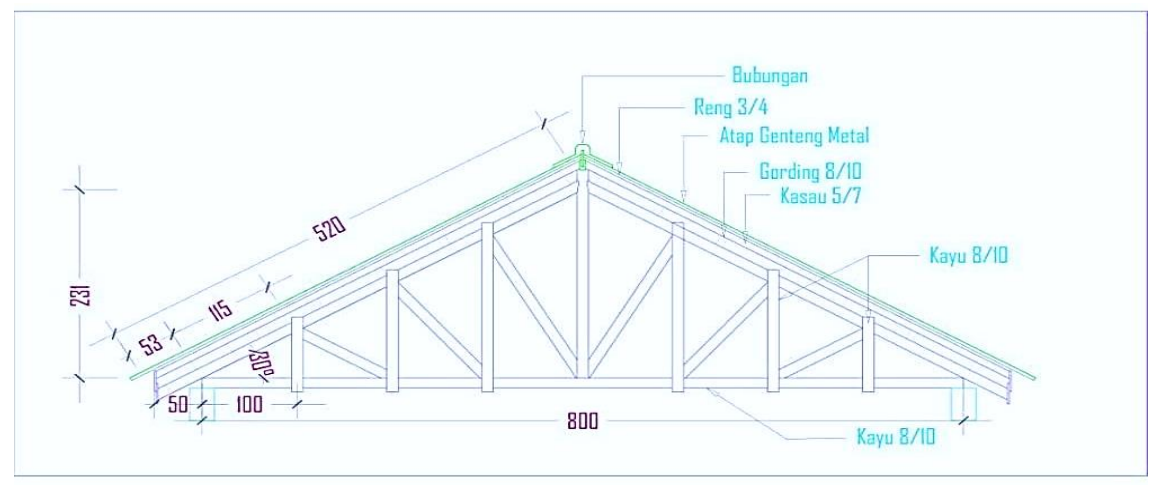

Sumber : Data Olahan, 2019

\section{Gambar 1. Konstruksi Rangka Atap kayu}

\section{Konstruksi Rangka Atap Baja Ringan}

Konstruksi Rangka Atap Baja Ringan adalah konstruksi atap yang strukturnya tidak jauh berbeda dengan konstruksi rangka atap kayu, hanya saja bahan pembuatnya dari bahan baja ringan atau sering disebut truss. Rangka atap (kuda kuda) baja ringan adalah rangka yang terbuat dan baja lapis Zincalume dengan kandungan Alumunium, Zinc, dan Silikon.Baja ringan 6-7 kg/m², bandingkan dengan kayu yang biasa mencapai $20 \mathrm{~kg} / \mathrm{m}^{2}$, terbukti bahwa baja ringan memang ringan.

Baja ringan merupakan baja profil yang dibentuk dalam keadaan dingin (cold formed steel) yang material nya berupa lembaran plat baja dengan ketebalan antara $0,4 \mathrm{~mm}$ sampai $1,10 \mathrm{~mm}$ (SNI 8399:2017). Dalam perakitan struktur rangka atap baja ringan, perlu diperhatikan ketentuan pemilihan jarak antar kuda-kuda. Semakin besar beban yang harus dipikul, jarak kuda-kuda akan semakin pendek (Salmon, 2000). Misalkan untuk genteng dengan bobot $40 \mathrm{~kg} / \mathrm{m}^{2}$ jarak kuda-kuda bisa dibuat setiap 1,4m.Sementara bila bobot genteng mencapai $75 / \mathrm{kg} / \mathrm{m}^{2}$, maka jarak kuda-kuda menjadi $1,2 \mathrm{~m}$.

Selain jarak antar kuda-kuda, perlu di perhatikan pemasangan alat sambung agar diperoleh sistem struktur yang stabil, kuat, dan tidak merusak lapisan anti karat. Alat sambung yang digunakan biasanya berupa sekrup.

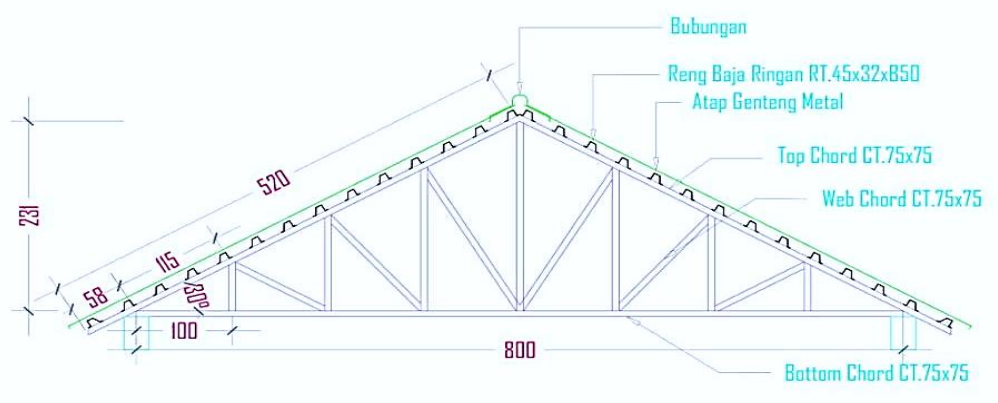

Gambar 2. Konstruksi Rangka Atap Baja Ringan 


\section{METODE}

Penelitian dilakukan dengan melakukan prosedur/rancangan kerja sebagai berikut:

1. Mendesain kuda-kuda dengan bentang $8 \mathrm{~m}$ menggunakan rangka atap kayu dan rangka atap baja.

2. Menghitung harga satuan pekerjaan (HSP) yang akan digunakan dalam perencanaan Rencana Anggaran Biaya (RAB) khusus untuk pekerjaan rangka atap.

3. Mencari jarak optimal dari penggunaan rangka atap baja ringan dan rangka atap kayu.

4. Membandingkan (komparasi) pemakaian kedua bahan tersebut dari segi biaya.

Software yang digunakan dalam penggambaran system rangka atap ini adalah AUTOCAD versi 2007 yang merupakan produk keluaran AUTODESK Corporation yang sudah sangat umum dipakai dalam desain dan grafis dibidang teknik sipil dan arsitektur. Dan analisis gaya batang dan lendutan menggunakan software SAP 2000.

\section{HASIL DAN PEMBAHASAN}

\section{Pembebanan Pada Struktur Kayu}

Beban mati, beban hidup, dan beban angin yang bekerja pada struktur dapat dilihat sebagai berikut:

Tabel 1. Pembebanan pada Struktur Kayu

\begin{tabular}{|c|c|c|c|c|c|}
\hline \multirow{2}{*}{ No } & \multirow{2}{*}{$\begin{array}{c}\text { Jarak } \\
\text { kuda-kuda }\end{array}$} & \multirow{2}{*}{$\begin{array}{c}\text { Beban mati } \\
\mathrm{Kg}\end{array}$} & \multirow{2}{*}{$\begin{array}{c}\text { Beban hidup } \\
\mathrm{kg}\end{array}$} & \multicolumn{2}{|c|}{ Beban angin $\mathrm{Kg} / \mathrm{m}$} \\
\hline & & & & Angin tekan & Angin hisap \\
\hline \multirow{2}{*}{1} & \multirow{2}{*}{$1,5 \mathrm{~m}$} & \multirow{2}{*}{67,90} & \multirow{2}{*}{100} & 3,93 & $-7,87$ \\
\hline & & & & 7,72 & $-15,44$ \\
\hline \multirow{2}{*}{2} & \multirow{2}{*}{$2 \mathrm{~m}$} & \multirow{2}{*}{90,53} & \multirow{2}{*}{100} & 5,24 & $-10,49$ \\
\hline & & & & 10,29 & $-20,58$ \\
\hline \multirow{2}{*}{3} & \multirow{2}{*}{$2,25 \mathrm{~m}$} & \multirow{2}{*}{101,84} & \multirow{2}{*}{100} & 5,90 & $-11,80$ \\
\hline & & & & 11,58 & $-23,15$ \\
\hline \multirow{2}{*}{4} & \multirow{2}{*}{$2,5 \mathrm{~m}$} & \multirow{2}{*}{113,16} & \multirow{2}{*}{100} & 6,55 & $-13,11$ \\
\hline & & & & 12,86 & $-25,73$ \\
\hline \multirow{2}{*}{5} & \multirow{2}{*}{$3 m$} & \multirow{2}{*}{135,79} & \multirow{2}{*}{100} & 7,87 & $-15,73$ \\
\hline & & & & 15,44 & $-30,87$ \\
\hline
\end{tabular}

Sumber: Data Olahan, 2019

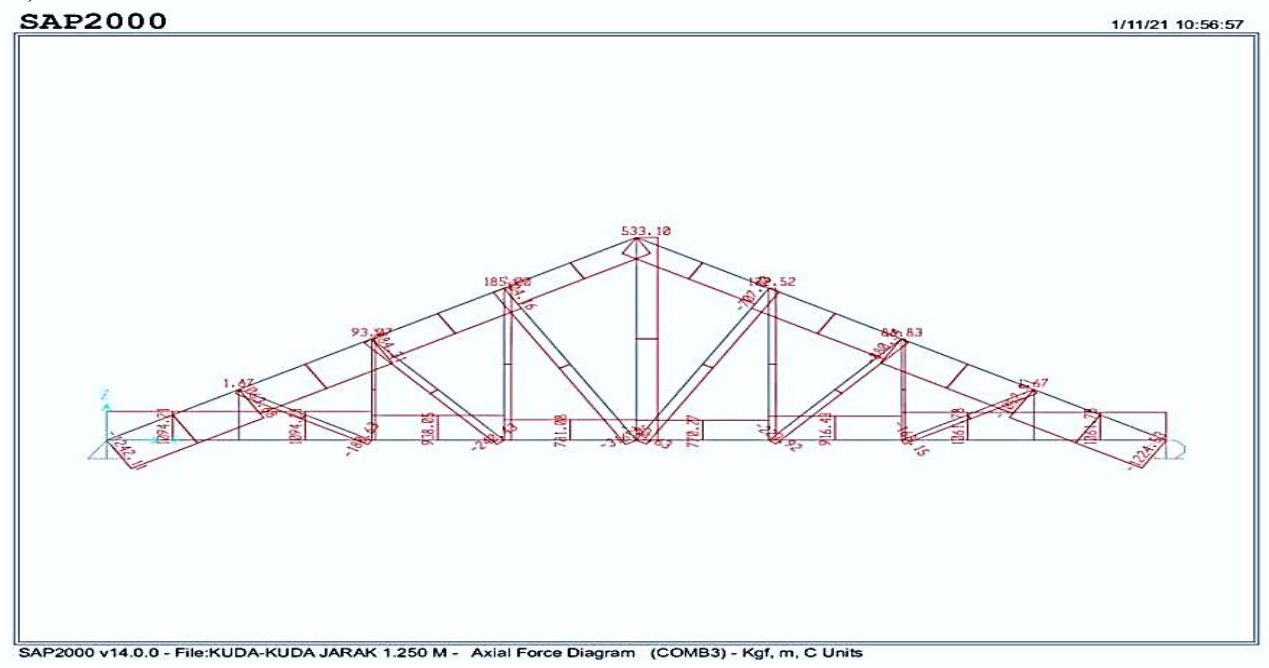

Sumber : Data Olahan, 2019

Gambar 3. Gaya Tekan dan Tarik Pada Struktur Kayu

Tabel 2. Lendutan Struktur Kayu Lendutan < F ijin $26.6 \mathrm{~mm}$

\begin{tabular}{ccccc}
\hline Bentang & Jarak Kuda-kuda & Jenis penutup atap & Lendutan & Keterangan \\
\hline $8 \mathrm{~m}$ & $1,5 \mathrm{~m}$ & Genteng Metal & $3,296 \mathrm{~mm}$ & aman \\
$8 \mathrm{~m}$ & $2 \mathrm{~m}$ & Genteng Metal & $3,662 \mathrm{~mm}$ & aman \\
$8 \mathrm{~m}$ & $2,25 \mathrm{~m}$ & Genteng Metal & $3,823 \mathrm{~mm}$ & aman \\
$8 \mathrm{~m}$ & $2,5 \mathrm{~m}$ & Genteng Metal & $3,984 \mathrm{~mm}$ & aman \\
$8 \mathrm{~m}$ & $3 \mathrm{~m}$ & Genteng Metal & $4,306 \mathrm{~mm}$ & aman \\
\hline
\end{tabular}

Sumber : Hasil Output SAP 2000, 2019 
M. Riza Primadani, Suhendra dan Eri Dahlan, Perencanaan Baja Ringan Sebagai Salah Satu Alternatif Pengganti Kayu Pada Struktur Rangka Atap Bangunan

Tabel 3. Tegangan Struktur kayu Tegangan $<\sigma$ ijin $106,25 \mathrm{Kg} / \mathrm{cm}^{2}$

\begin{tabular}{rccccccc}
\hline Bentang & $\begin{array}{c}\text { Jarak kuda - } \\
\text { kuda }\end{array}$ & gaya tekan (-) & gaya tarik & Tegangan & keterangan \\
\hline $8 \mathrm{~m}$ & $1,5 \mathrm{~m}$ & 1915,30 & $\mathrm{Kg}$ & 1951,18 & $\mathrm{~kg}$ & $24,39 \mathrm{Kg} / \mathrm{cm}^{2}$ & aman \\
$8 \mathrm{~m}$ & $2 \mathrm{~m}$ & 2094,93 & $\mathrm{Kg}$ & 2120,20 & $\mathrm{~kg}$ & $26,19 \mathrm{Kg} / \mathrm{cm}^{2}$ & aman \\
$8 \mathrm{~m}$ & $2,25 \mathrm{~m}$ & 2184,70 & $\mathrm{Kg}$ & 2204,68 & $\mathrm{Kg}$ & $27,31 \mathrm{Kg} / \mathrm{cm}^{2}$ & aman \\
$8 \mathrm{~m}$ & $2,5 \mathrm{~m}$ & 2274,50 & $\mathrm{Kg}$ & 2289,18 & $\mathrm{~kg}$ & $28,43 \mathrm{Kg} / \mathrm{cm}^{2}$ & aman \\
$8 \mathrm{~m}$ & $3 \mathrm{~m}$ & 2454,12 & $\mathrm{Kg}$ & 2458,21 & $\mathrm{~kg}$ & $30,68 \mathrm{Kg} / \mathrm{cm}^{2}$ & aman \\
\hline
\end{tabular}

Sumber : Hasil Output SAP 2000, 2019

\section{Pembebanan Pada Struktur Baja Ringan}

Beban mati, beban hidup, dan beban angin yang bekerja pada struktur dapat dilihat sebagai berikut :

Tabel 4. Pembebanan pada Struktur Baja Ringan

\begin{tabular}{|c|c|c|c|c|c|}
\hline \multirow{2}{*}{ No } & \multirow{2}{*}{$\begin{array}{c}\text { jarak } \\
\text { kuda-kuda }\end{array}$} & \multirow{2}{*}{$\begin{array}{c}\text { Beban mati } \\
\mathrm{Kg}\end{array}$} & \multirow{2}{*}{$\begin{array}{c}\text { Beban hidup } \\
\mathrm{Kg}\end{array}$} & \multicolumn{2}{|c|}{ Beban angin $\mathrm{Kg} / \mathrm{m}$} \\
\hline & & & & Angin tekan & Angin hisap \\
\hline \multirow{2}{*}{1} & \multirow{2}{*}{$1 \mathrm{~m}$} & \multirow{2}{*}{8,46} & \multirow{2}{*}{100} & 2,62 & $-5,24$ \\
\hline & & & & 5,15 & $-10,29$ \\
\hline \multirow{2}{*}{2} & \multirow{2}{*}{$1,25 \mathrm{~m}$} & \multirow{2}{*}{10,58} & \multirow{2}{*}{100} & 3,28 & $-6,55$ \\
\hline & & & & 6,43 & $-12,86$ \\
\hline \multirow{2}{*}{3} & \multirow{2}{*}{$1,5 \mathrm{~m}$} & \multirow{2}{*}{12,71} & \multirow{2}{*}{100} & 3,93 & $-7,87$ \\
\hline & & & & 7,72 & $-15,44$ \\
\hline \multirow{2}{*}{4} & \multirow{2}{*}{$1,75 \mathrm{~m}$} & \multirow{2}{*}{14,82} & \multirow{2}{*}{100} & 4,59 & $-9,18$ \\
\hline & & & & 9,00 & $-18,01$ \\
\hline \multirow{2}{*}{5} & \multirow{2}{*}{$2 \mathrm{~m}$} & \multirow{2}{*}{16,94} & \multirow{2}{*}{100} & 5,24 & $-10,49$ \\
\hline & & & & 10,29 & $-20,58$ \\
\hline
\end{tabular}

Sumber : Hasil Output SAP 2000, 2019

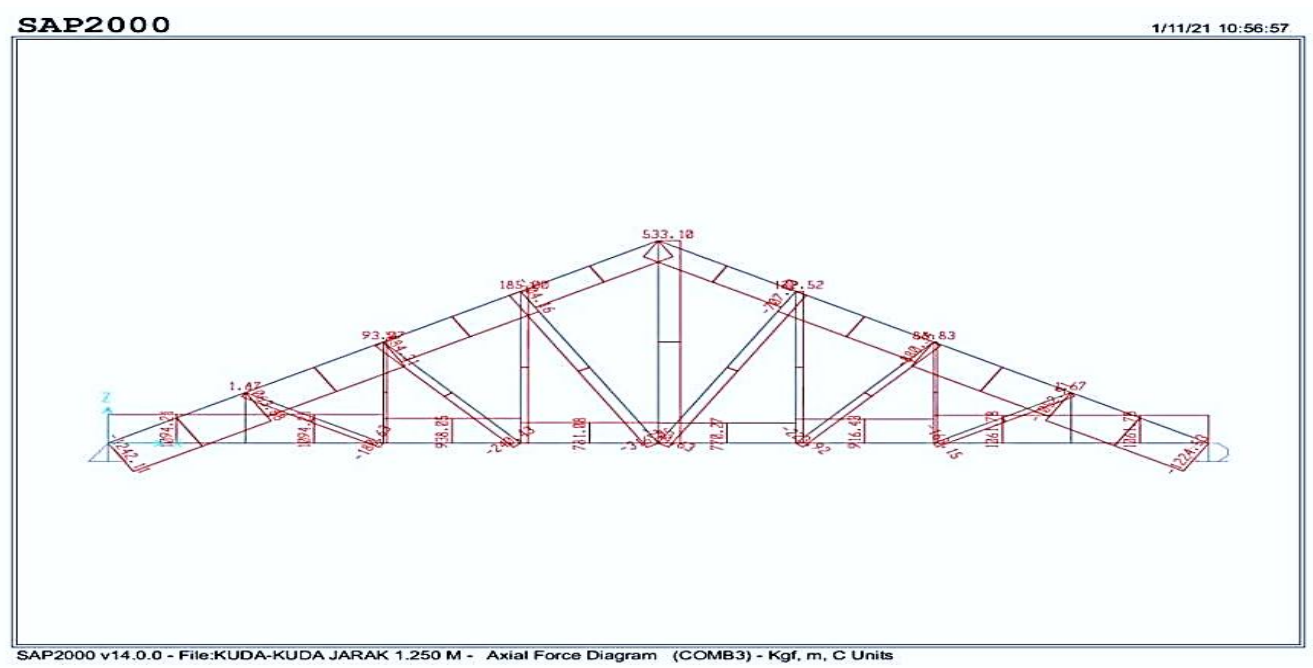

Sumber : Data Olahan, 2019

Gambar 4. Gaya Tekan dan Tarik Pada Struktur Baja Ringan

Tabel 5. Rekapitulasi Nilai Ratio Baja Ringan (Hasil Output SAP)

\begin{tabular}{ccccc}
\hline Bentang & Jarak Kuda-kuda & Jenis penutup atap & Nilai R & Keterangan \\
\hline $8 \mathrm{~m}$ & $1 \mathrm{~m}$ & Genteng Metal & 0,850 & Masih Aman \\
$8 \mathrm{~m}$ & $1,25 \mathrm{~m}$ & Genteng Metal & 0,863 & Masih Aman \\
$8 \mathrm{~m}$ & $1,5 \mathrm{~m}$ & Genteng Metal & 0,882 & Masih Aman \\
$8 \mathrm{~m}$ & $1,75 \mathrm{~m}$ & Genteng Metal & 0,898 & Masih Aman \\
$8 \mathrm{~m}$ & $2 \mathrm{~m}$ & Genteng Metal & 0,914 & Berbahaya \\
\hline
\end{tabular}

Sumber : Hasil Output SAP 2000, 2019 
M. Riza Primadani, Suhendra dan Eri Dahlan, Perencanaan Baja Ringan Sebagai Salah Satu Alternatif Pengganti Kayu Pada Struktur Rangka Atap Bangunan

Tabel 6. Lendutan Struktur Baja Ringan Lendutan $<$ F ijin 26,6mm

\begin{tabular}{ccccc}
\hline Bentang & Jarak Kuda-kuda & Jenis penutup atap & Lendutan & Keterangan \\
\hline $8 \mathrm{~m}$ & $1 \mathrm{~m}$ & Genteng Metal & $6,22 \mathrm{~mm}$ & aman \\
$8 \mathrm{~m}$ & $1,25 \mathrm{~m}$ & Genteng Metal & $6,31 \mathrm{~mm}$ & aman \\
$8 \mathrm{~m}$ & $1,5 \mathrm{~m}$ & Genteng Metal & $6,40 \mathrm{~mm}$ & aman \\
$8 \mathrm{~m}$ & $1,75 \mathrm{~m}$ & Genteng Metal & $6,48 \mathrm{~mm}$ & aman \\
$8 \mathrm{~m}$ & $2 \mathrm{~m}$ & Genteng Metal & $6,57 \mathrm{~mm}$ & aman \\
\hline
\end{tabular}

Sumber : Hasil Output SAP 2000, 2019

Tabel 7. Tegangan Struktur Baja Ringan Tegangan $<\sigma$ ijin $5608,44 \mathrm{Kg} / \mathrm{cm}^{2}$

\begin{tabular}{ccllcccc}
\hline Bentang & Jarak kuda-kuda & gaya tekan $(-)$ & \multicolumn{2}{c}{ gaya tarik } & Tegangan & keterangan \\
\hline $8 \mathrm{~m}$ & $1 \mathrm{~m}$ & 1226,84 & $\mathrm{~kg}$ & 1077,12 & $\mathrm{~kg}$ & $1135,96 \mathrm{Kg} / \mathrm{cm}^{2}$ & aman \\
$8 \mathrm{~m}$ & $1,25 \mathrm{~m}$ & 1242,11 & $\mathrm{~kg}$ & 1094,21 & $\mathrm{~kg}$ & $1150,10 \mathrm{Kg} / \mathrm{cm}^{2}$ & aman \\
$8 \mathrm{~m}$ & $1,5 \mathrm{~m}$ & 1262,90 & $\mathrm{~kg}$ & 1116,88 & $\mathrm{Kg}$ & $1169,35 \mathrm{Kg} / \mathrm{cm}^{2}$ & aman \\
$8 \mathrm{~m}$ & $1,75 \mathrm{~m}$ & 1278,75 & $\mathrm{~kg}$ & 1133,4 & $\mathrm{~kg}$ & $1184,03 \mathrm{Kg} / \mathrm{cm}^{2}$ & aman \\
$8 \mathrm{~m}$ & $2 \mathrm{~m}$ & 1296,07 & $\mathrm{~kg}$ & 1152,16 & $\mathrm{~kg}$ & $1200,06 \mathrm{Kg} / \mathrm{cm}^{2}$ & aman \\
\hline
\end{tabular}

Sumber : Hasil Output SAP 2000, 2019

\section{Analisis Biaya Pemasangan Rangka Atap}

\section{Analisis Biaya Pemasangan Rangka Atap Kayu}

Untuk membuat rencana anggaran biaya pada analisis biaya rangka atap kayu tidak jauh berbeda dengan analisis biaya rangka atap baja ringan cara penyusunannya hanya saja daftar analisis harga satuan upah pekerja dan rencana anggaran biaya (RAB) yang berbeda.

Tabel 8. Daftar Harga Material Rangka Atap Kayu

\begin{tabular}{llclr}
\hline No & \multicolumn{2}{c}{ JenisBahanAtap } & Satuan & \multicolumn{2}{c}{ HargaSatuan } \\
\hline & Pekerjaan Atap & & & \\
1 & Kayu Kelas II 8/10 & $\mathrm{m}^{3}$ & $\mathrm{Rp}$. & $2.700 .000,-$ \\
2 & Kayu Kelas II 5/7 & $\mathrm{m}^{3}$ & $\mathrm{Rp}$. & $2.700 .000,-$ \\
3 & Kayu Kelas II 3/4 & $\mathrm{m}^{3}$ & $\mathrm{Rp}$. & $2.700 .000,-$ \\
4 & Paku 5 dan 10 cm & $\mathrm{Kg}$ & $\mathrm{Rp}$. & $36.000,-$ \\
5 & Paku 12 cm & $\mathrm{Kg}$ & $\mathrm{Rp}$. & $36.000,-$ \\
6 & Besi Strip Tebal5mm & $\mathrm{Kg}$ & $\mathrm{Rp}$. & $20.000,-$ \\
7 & Genteng Metal & Lbr & Rp. & $100.000,-$ \\
\hline
\end{tabular}

Sumber : Peraturan Bupati Tanjung Jabung Barat No 745/kep.bup/bpkad/2018

Tabel 9. Pemasangan $1 \mathrm{m3}$ Konstruksi kuda-kuda konvensional, Kayu kelas II

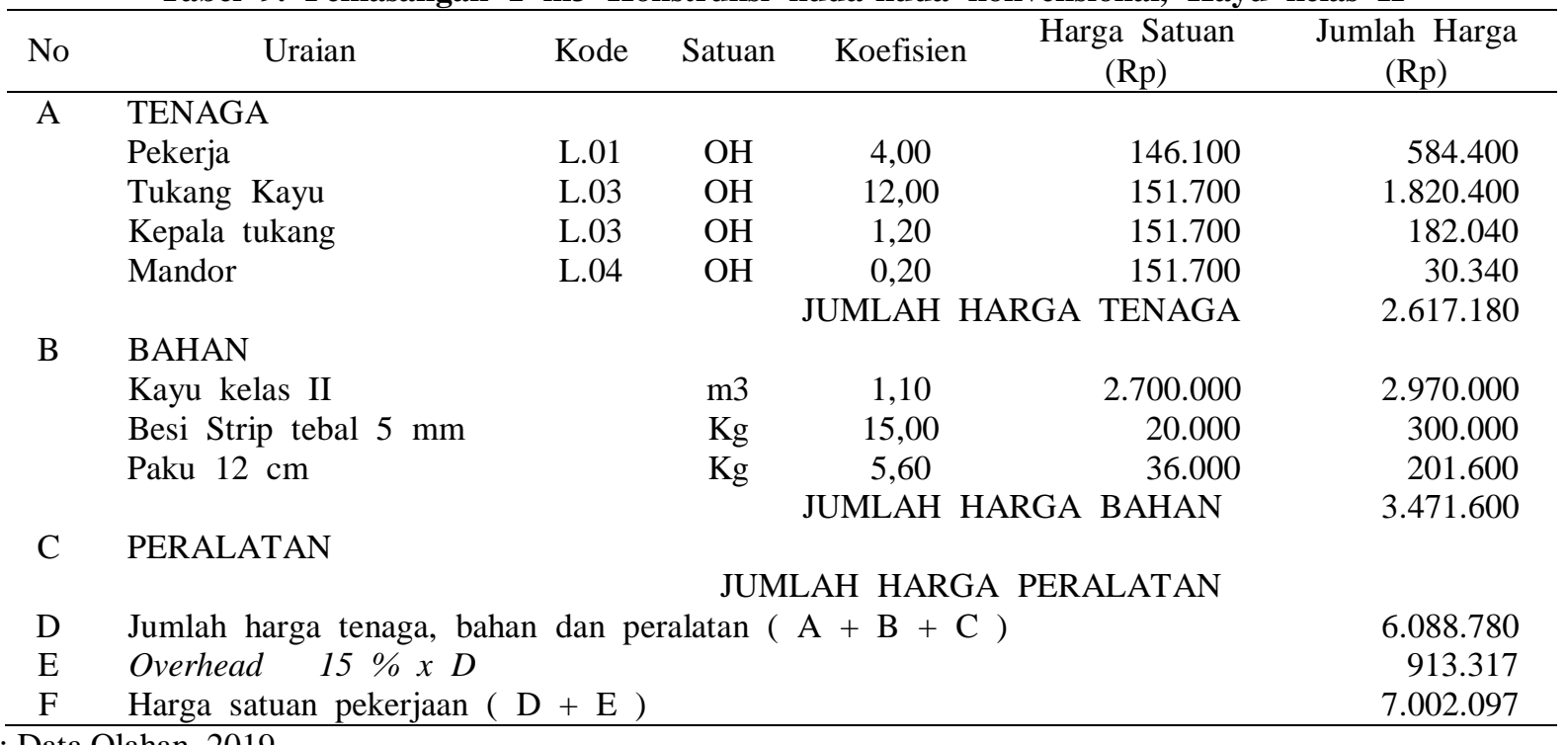

Sumber : Data Olahan, 2019 


\section{Analisis Biaya Pemasangan Rangka Atap Baja Ringan}

Untuk membuat rencana anggaran biaya pada analisis biaya rangka atap baja ringan yang harus dikerjakan terlebih dahulu mengetahui daftar harga satuan upah dan bahan.Setelah itu dilanjutkan membuat rencana anggaran biaya.

Tabel 10. Daftar Harga Material Rangka Atap Baja Ringan

\begin{tabular}{clllr}
\hline No & \multicolumn{1}{c}{ JenisBahanAtap } & Satuan & \multicolumn{2}{c}{ HargaSatuan } \\
\hline \multicolumn{2}{c}{ Pekerjaan Atap } & & & \\
1 & Baja Ringan C75.75 & Btg & Rp. & $98.000,-$ \\
2 & Baja Ringan C75.100 & Btg & Rp. & $120.000,-$ \\
3 & Reng Taso R32.45 & Btg & Rp. & $45.000,-$ \\
4 & Screw 10x16mm & Kg & Rp. & $15.000,-$ \\
5 & Dynabolt 12x120mm & Bh & Rp. & $3.500,-$ \\
6 & Genteng Metal & Lbr & Rp. & $100.000,-$ \\
7 & Paku Biasa 1/2"-1" & Kg & Rp. & $22.000,-$ \\
\hline
\end{tabular}

Sumber :Peraturan Bupati Tanjung Jabung Barat No 745/kep.bup/bpkad/2018

Tabel 11. Pemasangan $1 \mathrm{~m}^{2}$ atap pelana rangka atap baja canai dingin $\mathbf{c 7 5}$

\begin{tabular}{|c|c|c|c|c|c|c|}
\hline No & Uraian & Kode & Satuan & Koef & Harga Satuan (Rp) & $\begin{array}{l}\text { Jumlah Harga } \\
\text { (Rp) }\end{array}$ \\
\hline \multirow[t]{6}{*}{ A } & TENAGA & & & & & \\
\hline & Pekerja & L.01 & $\mathrm{OH}$ & 0,734 & 146.100 & $107.237,40$ \\
\hline & Tukang besi & L.02 & $\mathrm{OH}$ & 0,734 & 151.700 & $111.347,80$ \\
\hline & Kepala tukang & L.03 & $\mathrm{OH}$ & 0,073 & 151.700 & $11.074,10$ \\
\hline & Mandor & L.04 & $\mathrm{OH}$ & 0,037 & 151.700 & $5.612,90$ \\
\hline & & & \multicolumn{3}{|c|}{ JUMLAH HARGA TENAGA } & $235.272,20$ \\
\hline \multirow[t]{6}{*}{$\mathrm{B}$} & BAHAN & & & & & \\
\hline & $\begin{array}{l}\text { Baja Ringan Canai } \\
\text { Dingin C75 }\end{array}$ & & $\mathbf{M}^{\prime}$ & 3,72 & 16.333 & 60.760 \\
\hline & Baut (Srew driver) & & bh & 28,00 & 150 & 4.200 \\
\hline & $\begin{array}{l}\text { Dynabol dia } 12 \text { x } 120 \\
\text { mm }\end{array}$ & & bh & 2,00 & 3.500 & 7.000 \\
\hline & Reng Canai Dingin & & $\mathbf{M}^{\prime}$ & 5,40 & 7.500 & 40.500 \\
\hline & & & \multicolumn{3}{|c|}{ JUMLAH HARGA BAHAN } & 112.460 \\
\hline \multirow[t]{3}{*}{$\mathrm{C}$} & PERALATAN & & & & & \\
\hline & Peralatan & & \multirow{2}{*}{\multicolumn{2}{|c|}{$\begin{array}{l}\% \quad 10,00 \\
\text { JUMLAH HA }\end{array}$}} & & 11.246 \\
\hline & & & & & RGA PERALATAN & 11.246 \\
\hline $\mathrm{D}$ & \multicolumn{5}{|c|}{ Jumlah harga tenaga, bahan dan peralatan $(A+B+C)$} & $358.978,20$ \\
\hline $\mathrm{E}$ & \multicolumn{5}{|c|}{ Overhead $15 \% \times D$} & $53.846,73$ \\
\hline $\mathrm{F}$ & \multicolumn{5}{|c|}{ Harga satuan pekerjaan ( $D+E)$} & $412.824,93$ \\
\hline
\end{tabular}

Rekapitulasi Dana yang di hitung :

Tabel 12. Rekapitulasi Rencana Anggaran Biaya ( RAB )

\begin{tabular}{clcrrr}
\hline No & \multicolumn{1}{c}{ Uraian Pekerjaan } & Volume & Satuan & AHSP (Rp) & $\begin{array}{c}\text { Harga Satuan } \\
(\mathrm{Rp})\end{array}$ \\
\hline & $\quad$ Rangka Atap Kayu & & & & \\
1 & Kuda-Kuda kayu & 1,923 & $\mathrm{~m}^{3}$ & 7.002 .097 & 13.465 .033 \\
2 & Rangka Atap & 101 & $\mathrm{~m}^{2}$ & 267.669 & 27.034 .551 \\
3 & Genteng Metal & 104 & $\mathrm{~m}^{2}$ & 207.528 & 21.582 .861 \\
& Rangka Atap Baja Ringan & & & Jumlah & 62.082 .444 \\
& Kuda-kuda Baja Ringan & 101 & $\mathrm{~m}^{2}$ & 412.825 & 41.695 .318 \\
6 & Genteng & 104 & $\mathrm{~m}^{2}$ & 207.528 & 21.582 .912 \\
& & & & Jumlah & 63.278 .178 \\
\hline
\end{tabular}

Sumber : Data Olahan, 2019 


\section{KESIMPULAN}

1. Perbandingan rangka atap baja ringan dan rangka atap kayu dilakukan terhadap kekuatan struktur dan rencana anggaran biaya.

2. Terdapat perbedaan biaya pada rangka atap yaitu dari hasil analisis biaya pada pembangunan rangka Atap Baja Ringan dengan luas $72 \mathrm{~m}^{2}$ didapatkan total biaya yang dikeluarkan sebesar Rp.63.278.178, Sedangkan untuk kontruksi rangka atap kayu total biaya yang dikeluarkan sebesar Rp.62.082.444

3. Perbandingan biaya pada pembangunan rangka atap baja ringan dan rangka atap kayu adalah sebesar Rp.1.195.734. Jadi kesimpulan yang bisa di ambil dari kedua perbandingan biaya tersebut adalah pembuatan rangka atap menggunakan rangka atap baja ringan lebih mahal dari pada biaya menggunakan rangka atap kayu. Peneliti menggunakan material kayu meranti kelas II dan material baja menggunakan Baja Ringan C75.75.

4. Persentase harga pada kuda-kuda baja ringan $101,93 \%$ kali harga pada kuda-kuda kayu. Dan persentase berat kuda-kuda baja ringan $11,25 \%$ dari berat kuda-kuda kayu.

\section{DAFTAR PUSTAKA}

Hesna, Yevri dkk, 2009.Komparasi Penggunaan Kayu Dan Baja Ringan Sebagai Konstruksi Rangka Atap. Universitas Andalas. Padang.

Hilman Yusuf, 2009.Studi Perbandingan Rangka Atap Baja Ringan Pryda Dengan Rangka Atap Kayu Konvensional, Depok.

Lampiran Permen PUPR No 28/PRT/M AHSP bidang pekerjaan umum (2016).

Oktarina, dkk. 2015. Analisa Perbandingan Rangka Atap Baja Ringan Dan Rangka Atap Kayu Dari Segi Analisis Struktur Dan Anggaran Biaya. Jurnal Kontruksia. Vol.7, No. 1.Lampung.

Ria,M , 2014, Baja Ringan Sebagai Pengganti Kayu Dalam Pembuatan Rangka Atap Bangunan Rumah Masyarakat.Jurnal Teknik Sipil dan Lingkungan.Vol.2, No. 4.Bengkulu.

Rohman,dkk. 2011.Perbandingan Harga Penggunaan Konstruksi Kayu Dan Baja Ringan Sebagai Konstruksi Rangka Atap Pada Bangunan Sederhana.Vol.12, No. 2.Madiun.

Sherly Anggun R, 2015. Analisis Perbandingan Rangka Atap Baja Ringan Dengan Rangka Atap Kayu Terhadap Mutu, Biaya Dan Waktu. Jurnal teknik sipil Vol.3, No.2.Bangka Belitung.

SNI 8399:2017 Profil Rangka Baja Ringan.

Wicaksono, 2011, Panduan Konsumen Memilih Konstruksi Baja Ringan, Yogyakarta,

Wildensyah,Iden. 2013. Rangka Atap Baja Ringan Untuk Semua, Bandung. 